\title{
Avoiding split attention in computer-based testing: Is neglecting additional information facilitative?
}

Citation for published version (APA):

Jarodzka, H., Janssen, N., Kirschner, P. A., \& Erkens, G. (2012). Avoiding split attention in computer-based testing: Is neglecting additional information facilitative?. Paper presented at SIG 6 \& 7 "Instructional Design" and "Learning and Instruction with Computers" , Bari, Italy.

Document status and date:

Published: 01/09/2012

Document Version:

Peer reviewed version

Document license:

CC BY-NC-ND

Please check the document version of this publication:

- A submitted manuscript is the version of the article upon submission and before peer-review. There can be important differences between the submitted version and the official published version of record. People interested in the research are advised to contact the author for the final version of the publication, or visit the DOI to the publisher's website.

- The final author version and the galley proof are versions of the publication after peer review.

- The final published version features the final layout of the paper including the volume, issue and page numbers.

Link to publication

\section{General rights}

Copyright and moral rights for the publications made accessible in the public portal are retained by the authors and/or other copyright owners and it is a condition of accessing publications that users recognise and abide by the legal requirements associated with these rights.

- Users may download and print one copy of any publication from the public portal for the purpose of private study or research.

- You may not further distribute the material or use it for any profit-making activity or commercial gain

- You may freely distribute the URL identifying the publication in the public portal.

If the publication is distributed under the terms of Article 25fa of the Dutch Copyright Act, indicated by the "Taverne" license above, please follow below link for the End User Agreement:

https://www.ou.nl/taverne-agreement

Take down policy

If you believe that this document breaches copyright please contact us at:

pure-support@ou.nl

providing details and we will investigate your claim.

Downloaded from https://research.ou.nl/ on date: 26 Apr. 2023 


\title{
Avoiding split attention in computer-based testing: Is neglecting additional information facilitative?
}

\author{
Halszka Jarodzka ${ }^{1}$, Noortje Janssen ${ }^{2}$, Paul A. Kirschner ${ }^{1}$, and Gijsbert Erkens ${ }^{2}$ \\ ${ }^{1}$ Open University of The Netherlands; ${ }^{2}$ Utrecht University \\ ${ }^{1}$ P.O. Box 2960, 6401 DL Heerlen, The Netherlands; Postbus 80140, 3508 TC Utrecht, the \\ Netherlands \\ Halszka.Jarodzka@OU.nl; N.Janssen3@students.UU.nl; Paul.Kirschner@OU.nl; G.Erkens@UU.nl
}

\begin{abstract}
This study investigated whether design guidelines for computer-based learning can be applied to computer-based testing (CBT). 22 students completed a CBT-exam with half of the questions presented in a split-screen format and half in an integrated format. Results show that students attended to all information in the integrated format while ignoring information in the split-format. Interestingly, they worked more efficiently in the split-format. A content analysis of the ignored information revealed that it was mostly not directly relevant to answering the questions and thus unnecessarily taxed students' mental effort. Consequences of these findings on CBT-design are discussed.
\end{abstract}

Keywords: split attention; computer based testing; eye tracking.

\section{Managing Mental Effort by Presenting Multi-Media Information Integrated}

Use of advanced technologies for education is increasing. In the Netherlands, for example, students take centrally organized examinations at the end of high school using technologies which incorporate different media (e.g., video, sound, animation). This creates an ecologically valid test-setting closer to the acquired knowledge and skills strived for than paper-based testing (e.g., in Fine-Arts education). However, not much is known about how to design such tests.

Cognitive Load Theory (Sweller, 1994) provides guidelines for designing computer-based learning environments such that they can be processed by students (in working memory; WM) without exceeding available cognitive capacity while allowing for germane learning activities (i.e., managing mental effort). One guideline is that information should be presented in a spatially integrated way, sparing students unnecessary search, and thus freeing up WM-capacity for learning (i.e., split-attention effect; Chandler \& Sweller, 1991). This study investigated whether this guideline also facilitates CBT.

\section{Method}

\section{Participants}

22 students in the 5th year of secondary education ( 21 females; mean age $=16.36$ years) participated voluntarily in this study and were rewarded with a $€ 5.00$ gift voucher.

\section{Procedure, Material, and Apparatus}

Participants completed an authentic computer-based Fine Arts exam. The test items were - by default presented in a split-screen format (Figure 1 right). In this study, an additional integrated format of these items was designed (Figure 1 left). Each item was composed of an explanatory text, additional background information (textual or pictorial), and the test question presented together with a placeholder to write the answer. Each participant received four items in a split format and four in an integrated format in an alternating order (within-subjects design).

While completing the tests, participants' eye movements were recorded with a Tobii 1750 remote eye tracker. Moreover, participants were asked to rate their perceived mental effort after each test item on a 9-point rating scale (Paas, 1992). 


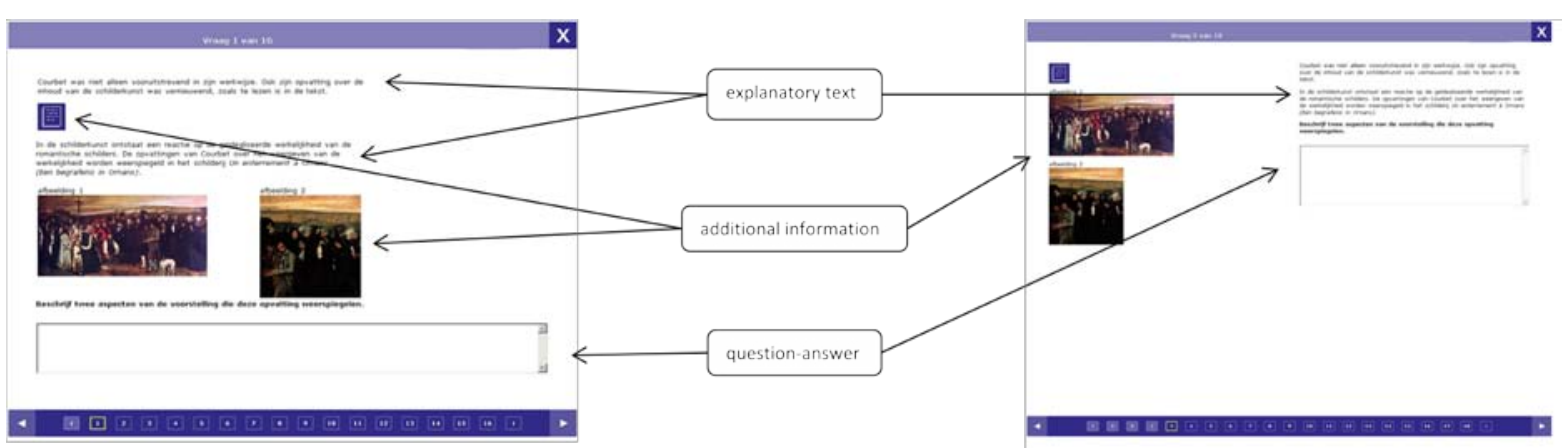

Figure 1. Two versions of the same test item used in this study.

\section{Data Analysis}

Participants' answers were scored according to the guidelines applied when this test was used as central exam in Dutch schools the previous year. Next, these outcomes were converted into standardized efficiency measures by taking performance, time spent achieving it, and rating of perceived mental effort into account (Touvinen \& Paas, 2004).

To investigate which elements were most attended to in the two formats, the attention duration to different screen elements was calculated. Three element-types were defined, namely "explanatory text”, "question \& answer", and "additional information" (Figure 1). "Additional information” was further divided into textual information and pictorial information.

\section{Results}

\section{Efficiency}

A repeated-measures ANOVA was calculated with the within-subject factor 'presentation format' and the dependent variable 'efficiency'. Results show that the split format led to significantly more efficient results than the integrated format, $F(1,21)=79.91, p<.01$.

\section{Eye Tracking Parameters}

A repeated-measures MANOVA with the within-subject factor 'presentation format' and the dependent variable 'total fixation time spent on screen elements' was calculated. Results show a main effect for presentation format, $F(4,18)=5.45, p<.01$. Univariate tests show that both formats did not lead to different viewing times on 'explanatory text', $F(1,21)=2.16, p=.16$, nor on 'pictorial information', $F<1$. Rather, when completing an item in integrated format, participants looked significantly longer on 'textual information', $F(1,21)=6.84, p=.02$, and marginally shorter on 'question-answer', $F(1,21)=4.06, p=.06$, as compared to completing an item in the split format.

\section{Further Analyses}

After obtaining these unexpected results, the content of the textual information was analyzed in terms of relevancy; whether it contained information that would lead to a higher test performance score when included in the test answer. The analysis revealed that the additional text information was mostly irrelevant.

\section{Discussion and conclusions}

The study shows that the design of CBT that make use of multimedia influences what information students attend to. In an integrated format, students appear to be influenced to inspect all presented information, in contrast to a split-format. Even more important, the design affects the efficiency with which students complete the exams. Interestingly, students showed lower testing efficiency in the integrated-format than in the split-format. However, this relation is not as simple as initially assumed. 
Instead, the content of the presented information is crucial. If this information is irrelevant, a splitformat where this information is ignored is more efficient, while if it is relevant, an integrated format may be more efficient.

Based on this study, there is no simple relation between the design of CBT and testing efficiency. Additionally, other factors such as the content of the presented information have to be carefully considered.

\section{References}

Chandler, P., \& Sweller, J. (1991). Cognitive load theory and the format of instruction. Cognition and Instruction, 8, 293-332.

Paas, F. (1992). Training strategies for attaining transfer of problem-solving skill in statistics: A cognitive-load approach. Journal of Educational Psychology, 84, 429-434.

Sweller, J. (1994). Cognitive load theory, learning difficulty, and instructional design. Learning and Instruction, 4, 295-312.

Tuovinen, J.E., \& Paas, F. (2004). Exploring multidimensional approaches to the frefiency of instructional conditions. Instructional Science, 32, 133-152. 